\title{
Exploring Factors Contributing to the Success of Women Entrepreneurs in Malaysia
}

\author{
Azlin Shafinaz Arshad, Marziah Mokhtar, Afiza Azura Arshad, Arlinah Abdul Rashid
}

\begin{abstract}
The purpose of the study is to explore factors contributing to the success of women who embarked in entrepreneurship. The study was conducted on 150 women entrepreneur in Malaysia by distributing the survey questionnaire. using convenience sampling. The study found charisma and friendliness are the most crucial factors contributes to the success of women entrepreneur while government support is the least contributing factor. Factor analysis conducted on success factors of women entrepreneur in Malaysia categorized the factors into four constructs; Individual \& Social Characteristic, Marketing \& Business Support, Efficient Management and Customer Engagement. The study found that Customer Engagement Factor contribute the most to the success of women entrepreneur in Malaysia.
\end{abstract}

Keywords: Entrepreneur, Entrepreneurship, Success Factors, Women Entrepreneur.

\section{INTRODUCTION}

Entrepreneurs are known globally to be the utmost importance to the economy as many of its main activities act as economy's engine, enacting and empowering all monetary action. Entrepreneurs are catalyst agent for expansion and promotion of economic activities in every scope of economic life of a country with the introduction of new combinations, improvise on existing productive resources and at the same time create job opportunities to the society where investment in entrepreneurship provides greater chance towards an improved economy (2). Entrepreneurs refers to people who propose in starting business by organizing, managing and taking risk (3). Entrepreneurship has been acknowledged as one of the crucial aspects for many developing countries and is the engine of economic development in the past years as well as the foreseeable future. Entrepreneurship refers to individual's ability in identifying and discovering opportunity which gives benefit to the society (4). Entrepreneurship involved the creation of something new with added value by putting extra effort and time which comes with financial and social risks resulted in monetary rewards monetary and personal satisfaction (5) while (6) described entrepreneurship involves discover, evaluate and exploit opportunities with the intention to develop and come out with new goods and services.

Revised Manuscript Received on April 19, 2019. Entrepreneurship Development, Universiti Teknologi MARA, Malaysia

Marziah Mokhtar, Centre of Foundation Studies, Universiti Teknologi MARA, Malaysia.

Afiza Azura Arshad, Faculty of Business Management, Universiti Teknologi MARA, Malaysia.

Arlinah Abdul Rashid, Arshad Ayub Graduate Business School, Universiti Teknologi MARA, Malaysia. (1). The heart of any country's economy is the entrepreneur

Azlin Shafinaz Arshad, Malaysian Academy of SME \&

Entrepreneurship has been acknowledged as engine for economic development and is a catalytic agent especially in expanding and promoting for business activities all over the world (4). This is supported where entrepreneurship is among the core areas for any country's economy (7).

The importance of entrepreneurial activities cannot be denied as entrepreneurial activities are recognized as among the crucial sources for economic growth and employment opportunities for many nations (8). Although many researchers have put much effort to study entrepreneurship in Malaysia, not many studies focused into women (9-11). Hence, this study aim to explore factors that contribute to the success of women entrepreneurs in Malaysia. Studying factors which have an influence towards women entrepreneur success allows others to have a broader understanding of how to ensure the business success (12). In addition, this study will assist women entrepreneurs to expand their business globally.

\section{LITERATURE REVIEW}

Although several studies on the success factors of women entrepreneur around the world has been undertaken, studies on women entrepreneur in Malaysia are still insufficient. Some of the factors that were found influencing women entrepreneur success are human capital, networking, financial assistance and opportunity. (13) focuses on characteristics such need for achievement, risk taking, selfconfidence and creative and innovative that lead to women entrepreneur success while (14) looked into risk-taking, innovativeness and entrepreneurial competencies of women entrepreneur itself as contributor factors to success.

Women entrepreneurs in ASEAN countries are on the rise and many studies were conducted in ASEAN countries to find the motives behind the success of women entrepreneurs. An empirical study in Singapore revealed the reasons that inspire women to own a business and found higher need for achievement, higher need for dominance and moderate needs for affiliation and autonomy are among the success factors (15). Study on women entrepreneurs in Quang Tri Province, Central Vietnam discovered women business owner success is due to the values they possessed and their insights towards entrepreneurship (16). Study conducted in Indonesia on motivation of entrepreneurs found family members influences and their participation do have an impact towards their business success (17) while another study found among the challenges of women 
entrepreneur are difficult to get financing, difficult to find qualified workers, work-home conflict as well as low profit (18). Research on women entrepreneur in North Cyprus revealed the kay factors that lead to the success of women entrepreneur is pull factor comprises of self-determination, achievement-oriented and honesty (19-20).

Women entrepreneurs contributed greatly in ensuring the success of many nations (21). Studies of women-owned SMEs in Pahang, Malaysia discovered interest, life impulse, skills and environmental influence do have an impact on women involvement in business (22). Research in South Africa in the Gauteng province discovered lack of education and training, difficulty to obtain financing, discrimination on gender, and shortage of resources are among the issues faced by women entrepreneur (23). Similar study in Valencia, Spain discovered different internal and external factors affect the success of women entrepreneur (24).

Numerous studies were found to determine the success factors of women entrepreneur around the world. A study on women entrepreneur in Bangladesh found factors that contributes towards their success are technology accessibility, social skill, type of business, training \& motivation, social security \& freedom, assistance provided $\&$ easy regulation, support from family \& quality assurance and risk encounter (25) while study in UAE discovered personal, environmental factors and support given by government contributes greatly to women entrepreneur success (26). One study found that confidence, determination, and vision do influence rural women entrepreneur success (27) while in another study revealed pull and push factors on the other hand have some influence on the woman entrepreneurs success (28). Self-motivation, support from family members, social network and information and communication technology are among the factors that contributes significantly towards women entrepreneur success in southern Punjab, Pakistan (29). Environmental dimensions, family dimensions and personal attributes are crucial factors in influencing success of women entrepreneur in the state of Kelantan, Malaysia (30) while family members support is vital for the women entrepreneur success (31).

\section{METHODOLOGY}

Quantitative method using survey questionnaire was employed by distributing to women who are involved in entrepreneurship throughout Malaysia. A simple random sampling method is used in which from 150 respondents only 118 responded resulted into 78.6 percent response rate. The survey questionnaire was divided into two section. Section one identifies the background of respondents and the business while the second section determines the success factors of women entrepreneurs. Five-point Likert scale were used where $1=$ strongly disagrees, $2=$ disagree, $3=$ neither agree or disagree, $4=$ agree and $5=$ strongly agree . Data analysis used are factor analysis, reliability analysis and descriptive analysis.

\section{RESULTS \& FINDINGS}

The profiles of the respondent and their business are shown in Table 1. From a total of 118 responses usable, majority of the women entrepreneurs are above 40 years old with $56.6 \%$, followed with $14.4 \%$ for respondents aged between 35-39 years old and $11.9 \%$ aged between $30-34$ years. Only $15.3 \%$ respondents are below 30 years old. A total of $52.5 \%$ of these women entrepreneur is married, $25.4 \%$ are single mother, $11.9 \%$ are separated and 10.2 are still single. When asked about their academic qualifications, $50.9 \%$ has a diploma, bachelor's degree and master's degree, $11 \%$ had certificates qualification while $38.1 \%$ received tertiary education. A total of $72 \%$ of respondents registered their business as a sole proprietorship, $14.4 \%$ as a private limited company and 13.6 as a partnership. The business location of many women entrepreneurs is in the central region $(46.4 \%)$, southern region $(24.6 \%)$, northern region (17.8\%), eastern Malaysia (10.2\%) and east coast $(8 \%)$.

\begin{tabular}{|c|c|c|c|}
\hline \multicolumn{2}{|c|}{ VARIABLES } & $\begin{array}{l}\text { FREQUENC } \\
\text { Y }\end{array}$ & $\begin{array}{l}\text { PERCENTAG } \\
\text { E }\end{array}$ \\
\hline \multirow[t]{5}{*}{ Age } & Below 25 & 10 & 8.5 \\
\hline & $25-29$ & 8 & 6.8 \\
\hline & $30-34$ & 14 & 11.9 \\
\hline & $35-39$ & 17 & 14.4 \\
\hline & Above 40 & 69 & 58.5 \\
\hline \multirow{4}{*}{$\begin{array}{l}\text { Marital } \\
\text { Status }\end{array}$} & Single & 12 & 10.2 \\
\hline & Married & 62 & 52.5 \\
\hline & Separated & 14 & 11.9 \\
\hline & Divorcee & 30 & 25.4 \\
\hline \multirow[t]{6}{*}{$\begin{array}{l}\text { Education } \\
\text { 3ackgroun }\end{array}$} & Primary & 1 & .8 \\
\hline & Secondary & 44 & 37.3 \\
\hline & Certificate & 13 & 11.0 \\
\hline & Diploma & 29 & 24.6 \\
\hline & $\begin{array}{l}\text { Bachelor's } \\
\text { degree }\end{array}$ & 29 & 24.6 \\
\hline & Postgraduate & 2 & 1.7 \\
\hline \multirow{6}{*}{$\begin{array}{l}\text { 3usiness } \\
\text { Dwnership }\end{array}$} & Sole & 85 & 72.0 \\
\hline & $\begin{array}{l}\text { Proprietorshi } \\
\mathrm{p}\end{array}$ & & \\
\hline & Partnership & 16 & 13.6 \\
\hline & Private & 17 & 14.4 \\
\hline & Limited & & \\
\hline & Company & & \\
\hline \multirow{9}{*}{$\begin{array}{l}\text { Business } \\
\text { Location }\end{array}$} & Northern & 21 & 17.8 \\
\hline & Region & & \\
\hline & Central & 55 & 46.6 \\
\hline & Region & & \\
\hline & Southern & 29 & 24.6 \\
\hline & Region & & \\
\hline & East Coast & 1 & 0.8 \\
\hline & Eastern & 12 & 10.2 \\
\hline & Malaysia & & \\
\hline
\end{tabular}

The mean scores and standard deviation of factors contributes to women entrepreneur's success is presented Table 2. The mean scores for success factors of women entrepreneurs ranging between 3.10 to 4.22 . The study found the most important factors contributes to women entrepreneur success in Malaysia is friendliness and charisma $(M=4.22)$. The next important factor is position in 
society $(M=4.12)$, support of family and friends $(M=4.11)$ and hard work $(M=4.10)$. Women entrepreneurs in Malaysia indicate the least importance factors contributing to their business success is satisfactory government support $(\mathrm{M}=3.19)$.

Table 2: Mean Scores for Success Factors

\begin{tabular}{lll}
\hline & MEAN & STANDARD \\
SUCCESS FACTOR & DEVIATION \\
& SCORE &
\end{tabular}

\begin{tabular}{lcc}
\hline Good Management Skills & 3.84 & .599 \\
Good Customer Service & 3.81 & .640 \\
Charisma: Friendliness & 4.22 & .572 \\
Government Support & 3.19 & 1.080 \\
Appropriate Training & 3.56 & .948 \\
Access to Capital & 3.44 & .892 \\
Previous Business Experience & 3.68 & .892 \\
Support of Family and Friends & 4.11 & 1.093 \\
Marketing/Sales Promotion & 3.36 & .814 \\
Product at Competitive Price & 3.87 & 1.000 \\
Hard Work & 4.10 & .634 \\
Strategic Location & 3.66 & .789 \\
Social Skills & 4.05 & .917 \\
Ability to Manage Personnel & 3.61 & .582 \\
Maintenance of Accurate & 3.87 & .952 \\
Records & & .711 \\
\hline
\end{tabular}

In determining the factors contributes to women entrepreneur success in Malaysia, factor analysis is undertaken. Any items that has factor loading less than 0.6 was removed (32). One item which is access to capital is being removed leaving fifteen items for further analysis. The factor analysis loaded success factors into four main constructs; Individual \& Social Characteristic, Marketing \& Business Support, Proper Management and Customer Engagement. The items which are categorized as "Individual and Social Characteristics" comprise of products are offered at competitive price, hard work, supports received from family and friends, previous business experience, social skills and position in society. The second construct is categorized as "Marketing \& Business Support". The items include marketing/sales promotion, strategic business location, government support and the ability of managing personnel. The third factor consists of good management skills, appropriate training and maintenance of accurate record which are categorized as "Efficient Management" while the last factor is categorized as
"Customer Engagement". Items under this factor are the charisma and friendliness as well as having a good customer service. Based on the success factors identified, the reliability analysis using was conducted. Any value below 0.6 must be removed to determine the reliability of the items $(33,34)$. The reliability tests conducted found the factors to be above the recommended value. The KMO value of 0.760 shows the adequacy of sampling. From the factor analysis conducted, all factors are found to be significant where the four factors cumulatively explain $69.87 \%$ of the variance. The factor analysis and reliability analysis results are presented in Table 3.

Table 3: Factor Analysis and Cronbach's Alpha for Success Factors of Women Entrepreneurs SUCCESS FACTORS FACTOR ITEMS

\begin{tabular}{lcccc} 
& $\mathbf{1}$ & $\mathbf{2}$ & $\mathbf{3}$ & $\mathbf{4}$ \\
\hline Product at Competitive Price & .834 & & \\
Hard Work & .810 & \\
Support of Family and Friends & .792 \\
Previous Business Experience & .727 \\
Social Skills & .675 \\
Position in Society & .625
\end{tabular}

Access to Capital $(*)$

Marketing/Sales Promotion $\quad .842$

Strategic Location

Government Support $\quad .791$

Ability to Manage Personnel $\quad .776$

Good Management Skills $\quad .788$

Appropriate Training $\quad .744$

Maintenance of Accurate

Records

Charisma: Friendliness

Good Customer Service

.662

\begin{tabular}{|c|c|c|c|c|}
\hline Kaiser-Meyer-Olkin (KMO) & \multicolumn{3}{|c|}{0.760} & \\
\hline Eigenvalue & 6.185 & 2.092 & 1.884 & 1.018 \\
\hline Cum. Variance Explained (\%) & 38.653 & 51.729 & 63.502 & 69.864 \\
\hline Cronbach's Alpha (dimension) & .848 & .827 & .689 & .693 \\
\hline Overall Cronbach's Alpha & & .886 & & \\
\hline
\end{tabular}

(*) Loadings below 0.6

Table 4 presents the mean score of the four factors

Published By: 
contribute women entrepreneur success. Among all four factors, Customer Engagement $(\mathrm{M}=4.017)$ are found to be the most important factor to women entrepreneurs as it generates the highest mean followed with Individual \& Social Characteristics (M=3.989), Efficient Management $(\mathrm{M}=3.757)$ and Marketing \& Business Support $(\mathrm{M}=3.456)$.

Table 4: Descriptive and Inferential Analysis

\begin{tabular}{lrcc}
\hline CONSTRUCTS & $\begin{array}{c}\text { MEAN } \\
\text { SCORE }\end{array}$ & $\begin{array}{c}\text { STANDAR } \\
\text { DEVIATION }\end{array}$ \\
\hline $\begin{array}{c}\text { Individual \& Social } \\
\text { Characteristics } \\
\text { Marketing }\end{array}$ & 3.989 & 3.512 \\
$\begin{array}{c}\text { Business Support } \\
\text { Efficient }\end{array}$ & $\&$ & 3.456 & 3.212 \\
$\begin{array}{c}\text { Management } \\
\text { Customer }\end{array}$ & 3.757 & 1.805 \\
Engagement & 4.017 & 1.062 \\
\hline
\end{tabular}

\section{CONCLUSION}

Majority of the respondents agree that charisma: friendliness, position in society, support of family and friends and hard work are crucial to their success as the mean scores were all above 4 . This findings is consistent with studies past studies where supports from people close to you is crucial to ensure success in business ventured (10, $30,31,35)$. However, the present study discovered support from the government has the lowest mean score which indicate that these women entrepreneur are not in the know of various assistance offered by the government. This study supports findings conducted on Turkish entrepreneur's view where the government do not contribute to their business success (19). Similarly, many of the respondents did not use assistance provided by the government due to the complication of procedure and they did not know and aware of the services available (36). In addition, one study discovered there was a need to coordinate the roles of governmental agencies involved in entrepreneurship development in order to improve quality of entrepreneurship ecosystem of the country as some of the roles of these agencies are overlapping (37).

Finding of the current study opposed with earlier studies. SMEs in Serbia discovered there were seven factors that contributes to their success which are position in society, interpersonal skills, approval and support, competitive product/service, leadership skills, always to be informed and business reputation (38). SMEs in Turkey found six factors generated such as characteristics related to the individual, social connections, competition, management skills, reputation/social skills and market support (19).

\section{ACKNOWLEDGMENT}

The study is supported by University of Technology MARA under LESTARI Research Grant 2017 (600IRMI/Dana KCM 5/3/LESTARI (161/2017) entitled Women-Owned SMEs: Determining Their Motivational Factors Starting Up Business.

\section{REFERENCES}

1. Ogunlana F. The Role of Entrepreneurship as the Driver of Economic Growth: Centria University of Applied Sciences; 2018

2. Seth S. Why entrepreneurs are important for the economy. Investopedia Academy (Internet). 2015 September 17,2017 Available from: https://www.investopedia.com/articles/personalfinance/101414/why-entrepreneurs-areimportanteconomy.asp.

3. Madura J. Introduction to business: Cengage Learning; 2006.

4. Yusuf N, Albanawi NI. The role of entrepreneurship in economic development in Saudi Arabia. Business and Economic Journal. 2016;7(1):5

5. Hisrich RD, Peters MP, Sheperd DA. Entrepreneurship, International Edition. McGraw Hill, New York: USA 2005.

6. Shane SA. A general theory of entrepreneurship: The individual-opportunity nexus: Edward Elgar Publishing; 2003.

7. Ramadani V, Hisrich RD, Gërguri-Rashiti S. Female entrepreneurs in transition economies: insights from Albania, Macedonia and Kosovo. World Review of Entrepreneurship, Management and Sustainable Development. 2015;11(4):391-413.

8. EconomicCencus. Better Data for Better Future. Putrajaya.; 2016.

9. Friar JH, Meyer MH. Entrepreneurship and start-ups in the Boston region: Factors differentiating high-growth ventures from micro-ventures. Small Business Economics. 2003;21(2):145-52.

10. Abdul M, Gunasagaran K, Kamarudin NA, Mizanur M. Critical success factors and challenges of women entrepreneurs in Klang Valley, Malaysia. Journal of Advanced Research in Business and Management Studies. 2017;6(1):11.

11. Alam SS, Jani MFM, Omar NA. An empirical study of success factors of women entrepreneurs in southern region in Malaysia. International Journal of Economics and Finance. 2011;3(2):166-75.

12. Mutalib RA, Arshad R, Ismail N, Ahmad Z. Women and entrepreneurship: An overview of women entrepreneurship programs in Malaysia. JGD Special Issue on Social Entrepreneurship. 2015; 11:15-28.

13. Teoh WM-Y, Chong S. Improving women entrepreneurs in small and medium enterprises in Malaysia: policy recommendations. Communications of the IBIMA 2008;2(5):31-8

14. Rani ${ }^{1}$ SHA, Hashim N. Factors that Influence Women Entrepreneurial Success in Malaysia: a Conceptual Framework. International Journal of Research. 2017;16.

15. Kemkar M, Sharma J. Women entrepreneurship - Factors leading to Success of Women Led Enterprises. Research Journal of Management Sciences. 2016;5(9):5.

16. Lee J. The motivation of women entrepreneurs in Singapore. Women in Management Review. 1996;11(2):18-29.

17. Le QV, Raven PV. Woman entrepreneurship in rural Vietnam: Success and motivational factors. The Journal of Developing Areas. 2015;49(2):57-76.

18. Rachmania IN, Rakhmaniar M, Setyaningsih $S$ Influencing Factors of Entrepreneurial Development in Indonesia. Procedia Economics and Finance. 2012; 4:234-43.

19. Hasan FS, Almubarak MMS. Factors influencing women entrepreneurs' 
performance in SMEs. World Journal of Entrepreneurship, Management and Sustainable Development. 2016;12(2):82-101.

20. Toros E, Altinay M. Women Entrepreneurs as Employers. Active Learning: IntechOpen; 2018.

21. Kamaruddin L, Arshad AS, Osman CA, Buyong SZ. An Exploratory Study of Malaysian Women Entrepreneurs: What Drives Them into Business. ASEAN Entrepreneurship Journal. 2018;4(2):13.

22. Mahajar AJB, Yunus JBM. Factors that encourage women involvement in SMEs in Pahang, Malaysia. The Journal of Human Resource and Adult Learning. 2012;8(2):33.

23. Chinomona E, Maziriri ET. Women in action: Challenges facing women entrepreneurs in the Gauteng Province of South Africa. The International Business \& Economics Research Journal (Online). 2015;14(6):835.

24. Akehurst G, Simarro E, Mas-Tur A. Women entrepreneurship in small service firms: motivations, barriers and performance. The Service Industries Journal 2012;32(15):2489-505.

25. Sarker S, Palit M. Determinants of success factors of women entrepreneurs in Bangladesh-A study based on Khulna region. Business and Economic Research. 2014;4(2):237.

26. Gupta N, Mirchandani A. Investigating entrepreneurial success factors of women-owned SMEs in UAE Management Decision. 2018;56(1):219-32.

27. Hassan F, Ramli A, Desa NM. Rural women entrepreneurs in Malaysia: what drives their success? International Journal of Business and Management. 2014;9(4):10.

28. Ismail HC, Shamsudin FM, Chowdhury MS. An exploratory study of motivational factors on women entrepreneurship venturing in Malaysia. Business and Economic Research. 2012;2(1).

29. Abbas T, Abrar M, Saleem R, Iqbal A. What leads to success for women entrepreneurs? An empirical study of Southern Punjabi in Pakistan. Academic Research International. 2016;7(5):130.

30. Rashid KM, Ngah HC, Mohamed Z, Mansor N. Success factors among women entrepreneur in Malaysia. International Academic Research Journal of Business and Technology. 2015;1(2):28-36.

31. Mustapha M. Challenges and success factors of female entrepreneurs: Evidence from a developing country. International Review of Management and Marketing. 2016;6(4S):224-31

32. Hair J, Black W, Babin B, Anderson R, Tatham R. Multivariate data analysis. Cranbury: NJ: Pearson Education; 2009.

33. Loewenthal $\mathrm{K}$, Lewis $\mathrm{CA}$. An introduction to psychological tests and scales: Psychology Press; 2018.

34. Sekaran U, Bougie R. Research Methods For Business, A Skill Building Approach, John Willey \& Sons. Inc New York. 2003.

35. Javadian G, Singh RP. Examining successful Iranian women entrepreneurs: an exploratory study. Gender in Management: An International Journal. 2012;27(3):148 64.

36. Benzing C, Chu HM, Kara O. Entrepreneurs in Turkey: A factor analysis of motivations, success factors, and problems. Journal of small business management. 2009; 47(1):58-91.

37. Yusoff MNH, Yaacob MR, Aziz ZA. Why Malay Entrepreneurs Did Not Use Business Support Services in Malaysia? Journal of Business and Social Development. 2014;2(2):8

38. Yusoff WFW, Kian TS, Ahmad AR, Jusoh NQ. Fostering the Entrepreneurial Ecosystem: The Roles of
Government Agencies in Malaysia. Advanced Science Letters. 2018;24(5):3079-84.

39. 39. Stefanović I, Ranković L, Prokić S. Entrepreneurs' motivational factors: Empirical evidence from Serbia. Serbian Journal of Management. 2011;6(1):73-83

\section{AUTHORS PROFILE}

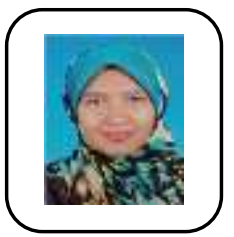

Azlin Shafinaz Arshad is a senior lecturer a Malaysian Academy of SME \& Entrepreneurship Development (MASMED), Universiti of Teknologi MARA (UiTM). Previously she holds the post as the Head of Department for Entrepreneurial Education in 2016 and in 2018 as the Head of Department for Entrepreneurial Research. She obtained her Doctor of Philosophy (Management) from Universiti Teknologi Malaysia (UTM) in 2016, Master of Business Administration from Universiti Teknologi MARA (UiTM), BBA (Hons) Finance from Universiti Teknologi MARA (UiTM) and Diploma in Accountancy also from Universiti MARA Malaysia (UiTM). Her research interest is in Entrepreneurship, Entrepreneurial Orientation, SMEs, Women Entrepreneurship, Entrepreneurial Intention, Leadership. She is a lifetime member of Malaysia Economics Association and Malaysian Consumers and Family Economics Association.

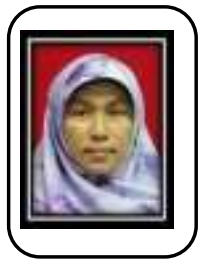

Marziah Mokhtar is a senior lecturer at Centre of Foundation Studies (CFS), Universiti of Teknologi MARA (UiTM). Previously she holds the position as Assistant Secretary of Innovation and Commercialization Unit, Ministry of Science, Head of Commercialization Unit at Research Innovation Unit, Universiti Teknologi MARA (UiTM) and now as MASMED Coordinator at Centre of Foundation Studies (CFS), Universiti of Teknologi MARA (UiTM). She obtained her Doctor of Philosophy (International Trade) from Universiti Kebangsaan Malaysia (UKM), Master of Business Administration from Universiti Teknologi MARA and a degree in Public Policy from Universiti Kebangsaan Malaysia (UKM). She is a lifetime member of Malaysia Economics Association and Malaysian Consumers and Family Economics Association.

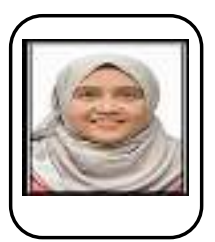

Afiza Azura Arshad is Senior Lecturer in Economics at Faculty of Business and Management, Universiti Teknologi MARA, Malaysia. She obtained her Master of Business Administration from Universiti Teknologi MARA and Bachelor of Science from University of Missouri, Rolla United States of America She is a lifetime member of Malaysia Economics Association and Malaysian Consumers and Family Economics Association.

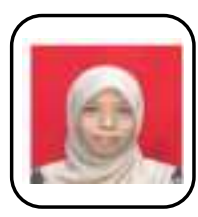

Arlinah Abdul Rashid is Senior Lecturer in Economics at Arshad Ayub Graduate Business School, Universiti Teknologi MARA, Malaysia. She holds a PhD in Economics from Lancaster University, United Kingdom, Master of Business Administration from Universiti Teknologi MARA and a degree in Economics from the University of Michigan, Ann Arbor. Her research interest are managerial economics, environmental economics and applied economics. She is a lifetime member of Malaysia Economics Association and Malaysian Consumers and Family Economics Association. 